\title{
GLYPHOSATE IN RUNOFF FROM URBAN, MIXED-USE AND AGRICULTURAL WATERSHEDS IN HAWAII, USA
}

\author{
STEVEN R. SPENGLER, MARVIN D. HESKETT \& SAMUEL C. SPENGLER \\ Element Environmental, Hawaii, USA
}

\begin{abstract}
High-frequency sampling and analysis was conducted for the broad-spectrum herbicide glyphosate (Roundup) in ephemeral and perennial streams receiving storm water runoff generated within agricultural, urban and mixed-used watersheds on the island of Oahu, Hawaii. Glyphosate was selected for analysis since it is the most widely used herbicide in the world, and as a result, tends to be ubiquitous in the environment and our food supply. Samples were collected under both baseflow and storm conditions from five streams. The pervasiveness and maximum concentration levels of glyphosate detected in these streams are greater than any other pesticide currently present in Hawaiian streams. Glyphosate was detected in $96 \%$ and $65 \%$ of the stream samples collected during storm events $(53$ samples) and under baseflow conditions (34 samples), respectively (detection limit $=0.05 \mu \mathrm{g} / \mathrm{L}$ ). The mean glyphosate concentrations measured in stream samples collected under storm conditions were between five to fifty times higher than mean glyphosate levels measured in the same stream under groundwater dominant baseflow conditions. The highest glyphosate concentrations were measured during a small runoff event in Manoa stream which flows through residential communities in urban Honolulu. The mass of dissolved phase glyphosate measured in stream water during the individual storm events monitored ranged from 0.5 to 18 grams. Between $11 \%$ and $23 \%$ of the total glyphosate load was present in suspended sediment during three sampled storm events in Honouliuli, Waimanalo and Kawa streams. The estimated total mass of dissolved phase glyphosate that discharged into Kaneohe Bay from Kawa Stream over a four-month monitoring period from December 2017 to March 2018 was 987 grams, with $92 \%$ of the pesticide load entering under storm conditions.
\end{abstract}

Keywords: glyphosate, streams, suspended sediment, Hawaii, Oahu.

\section{INTRODUCTION}

Pesticides have been applied to agricultural lands on the island of Oahu, Hawaii since the early 1900s. The annual amounts of herbicides historically applied on sugarcane and pineapple crops in Hawaii may have been as much as five times the amounts applied in major temperate region field crops elsewhere in the United States [1]. The intensive historical use of herbicides in Hawaii, year-round cultivation practices, and proximity of agricultural lands to streams enhance the possibility of pesticide transport to Oahu streams [2]. Some of the highest concentration levels of pesticides measured in fish during national water quality studies conducted by the United States Geological Survey (USGS) in the 1990s were detected in fish caught from urban Honolulu streams [3]. There is increasing public concern on the impact to human and ecological health from exposure to pesticides currently used in Hawaii and bills within the state legislature have recently moved ahead to regulate the use of glyphosate and chlorpyrifos. The USGS and Hawaii Department of Agriculture initiated a comprehensive pesticide-monitoring program of surface water in Hawaii in 2016 for 225 current-use pesticide compounds, but glyphosate is not among the compounds being monitored [4]. This study was conducted to provide data on the concentration levels of glyphosate in streams that flow through agricultural, residential and mixed-use areas on the island of Oahu under baseflow and storm conditions. 


\section{GLYPHOSATE}

Glyphosate is a non-selective herbicide that is widely used in agricultural, residential and commercial applications. Its most common mode of application is by direct spraying onto weeds. Its herbicidal activity is a result of glyphosate's ability to block a metabolic pathway involved in the synthesis of three aromatic amino acids (tyrosine, tryptophan, phenylalanine) which are essential for a plant's growth [5]. Glyphosate binds strongly to soils but is also very water soluble (more than $10,000 \mathrm{mg} / \mathrm{l}$ at $25^{\circ} \mathrm{C}$ ). Glyphosate degrades in the environment, primarily by microbial processes, to aminomethylphosphonic acid (AMPA). The half-life of glyphosate in water and soil is highly variable and longer than previously recognized. In field studies, the half-life of glyphosate in soil ranged between a few days to up to two years, depending on soil composition [6], [7]. Factors that control the amount of pesticides that may be transported to streams in runoff include the amount and intensity of rainfall, antecedent rainfall or irrigation, topography, soil type and condition, crop type and practices, pesticide application rates and timing, and pesticide properties. Pesticides such as glyphosate that adhere to soil particles may become liberated by rain events and either dissolve into or flow with surface water as suspended sediment, eventually ending up in stream bed sediments or coastal waters.

Glyphosate was first registered for use in the United States in 1974 and is now the world's most heavily applied herbicide. The use of glyphosate increased dramatically in the early 2000 s with the introduction of genetically-modified crops that are resistant to this herbicide. Annual farm-sector glyphosate usage in the United States increased to approximately 110 million kilograms by 2014 , based on average annual usage data reported by the United States Department of Agriculture [8]. In the agricultural sector, glyphosate is typically applied "post-emergence" after crops and weeds have emerged from the soil. Due to this mode of application, glyphosate is mainly stored in topsoil layers in agricultural soils. Hawaii's yearround growing season makes it an ideal location to develop new varieties of corn, soy and other commodity crops, since it often takes a dozen or more generations to develop a new hybrid plant that is ready for commercial distribution. As a result, pesticides including glyphosate are used throughout the year in Hawaii with the main growing season for seed crops extending from November to June.

Glyphosate is also commonly used by homeowners and for other nonagricultural purposes, the annual use of which quadrupled between 1993 and 2011 [9]. In urban settings glyphosate is widely approved for use by public works departments for weed control along streets, and within parks and public spaces. These urban applications are frequently on or near impervious surfaces and can result in substantial pesticide inputs to urban drainage systems [10]. For instance, Connor et al. [8] found that runoff from small-urbanized tributaries contribute as much or more to the pesticide loads to San Francisco Bay than runoff from the agricultural Central Valley, even though $90 \%$ of the freshwater flow to the bay comes from the Central Valley via the Sacramento and San Joaquin rivers.

\section{GLYPHOSATE LEVELS IN THE ENVIRONMENT}

The USGS has conducted the most comprehensive assessment of the environmental occurrence of glyphosate and its degradation product AMPA in the continental United States to date [12]. The USGS collected and analyzed a total of 3,732 water and sediment and 1,018 quality assurance samples from 38 states between 2001 and 2010 (no samples were collected from the State of Hawaii). This comprehensive study commonly detected either glyphosate or AMPA in surface water (59\% detection frequency from 470 sampled sites) and infrequently in groundwater or soil water samples (8.4\% detection frequency from 820 sampled sites). The European Glyphosate Environmental Information Sources (EGEIS) 
summarized surface water (50,000 samples) and groundwater (36,000 samples) monitoring data collected from thirteen European countries between 1993 and 2009 [13]. Glyphosate and AMPA were detected in $29 \%$ and $50 \%$ of the surface water samples analyzed, respectively. Glyphosate was detected in $1.3 \%$ of the groundwater samples collected from 8,900 localities throughout Europe. Glyphosate was also detected in $60 \%$ and $100 \%$ of air and rain samples collected from agricultural areas in Mississippi and Iowa [14]. Measured glyphosate concentrations ranged from $<0.01$ to $9.1 \mathrm{ng} / \mathrm{m}^{3}$ in air samples and from 0.1 to 2.5 $\mu \mathrm{g} / \mathrm{L}$ in rain samples.

The State of Hawaii Department of Health detected glyphosate in three of seven surface water sampling sites analyzed on the islands of Oahu and Kauai in 2014 [15]. Glyphosate and AMPA were detected in all seven co-located sediment samples at concentrations ranging from 6.8 to 1,100 and 7.5 to $1,200 \mu \mathrm{g} / \mathrm{kg}$, respectively. The Surfrider Foundation conducted a multi-year water quality study evaluating the concentration of pesticides and herbicides in the nearshore marine environments on the islands of Oahu and Kauai [16]. A total of 59 water samples and 32 co-located sediment samples were collected between 2015 and 2017. All the stream samples collected were analyzed for glyphosate using the immunoassay-based ELISA method. Glyphosate was detected in $60 \%$ of the stream samples collected at concentrations ranging from 0.070 to greater than $4.0 \mu \mathrm{g} / \mathrm{L}$ (parts per billion). Glyphosate was detected in $74 \%$ of the sediment samples collected at concentrations ranging from 33 to $5,500 \mu \mathrm{g} / \mathrm{kg}$ (parts per billion) while AMPA was detected in $100 \%$ of the sediment samples at concentrations ranging from 18 to $6,900 \mu \mathrm{g} / \mathrm{kg}$.

Table 1 summarizes the glyphosate concentrations measured and frequency of detection in stream samples collected during the $\mathrm{HDOH}$ and Surfrider Foundation studies in Hawaii and the during the various USGS studies conducted within the continental United States [12]. Overall, the median and mean glyphosate concentrations measured in Hawaiian streams (0.16

Table 1: Summary of glyphosate concentrations measured in streams in Hawaii and the continental United States.

\begin{tabular}{|c|c|c|c|c|c|c|}
\hline \multirow[b]{2}{*}{ State - basins sampled } & Median & Mean & Max. & Min. & \multirow[b]{2}{*}{$\begin{array}{l}\text { Number of } \\
\text { detects }\end{array}$} & \multirow[b]{2}{*}{$\begin{array}{l}\text { Frequency } \\
\text { of detection }\end{array}$} \\
\hline & \multicolumn{4}{|c|}{$\begin{array}{c}\text { Detected stream sample } \\
\text { glyphosate concentrations }(\mu \mathrm{g} / \mathrm{L})\end{array}$} & & \\
\hline Hawaii - Oahu and Kauai & 0.16 & 0.76 & 6.0 & 0.03 & 36 & $58 \%$ \\
\hline $\begin{array}{c}\text { California - San Joaquin- } \\
\text { Tulare Basin } \\
\end{array}$ & 0.35 & 1.44 & 7.7 & 0.10 & 25 & $33 \%$ \\
\hline Oregon - Willamette Basin & 0.35 & 0.41 & 0.86 & 0.12 & 18 & $72 \%$ \\
\hline Washington - State-wide & 0.64 & 0.67 & 2.0 & 0.10 & 18 & $62 \%$ \\
\hline $\begin{array}{c}\text { Washington - Columbia } \\
\text { Plateau }\end{array}$ & 0.19 & 0.37 & 0.88 & 0.11 & 10 & $40 \%$ \\
\hline Washington - Puget Sound & 0.07 & 0.12 & 0.53 & 0.02 & 17 & $55 \%$ \\
\hline $\begin{array}{c}\text { Nevada - Las Vegas, } \\
\text { Carson and Truckee Basins }\end{array}$ & 0.55 & 0.61 & 2.0 & 0.28 & 17 & $55 \%$ \\
\hline $\begin{array}{c}\text { Mississippi, Tennessee, } \\
\text { Arkansas - Mississippi } \\
\text { Embayment }\end{array}$ & 0.37 & 0.64 & 2.4 & 0.08 & 40 & $71 \%$ \\
\hline Mississippi River & 0.36 & 1.72 & 99.0 & 0.10 & 99 & $83 \%$ \\
\hline Nebraska - Central Basin & 0.26 & 0.54 & 9.7 & 0.05 & 61 & $54 \%$ \\
\hline South Dakota - Statewide & 0.10 & 0.16 & 0.66 & 0.04 & 15 & $65 \%$ \\
\hline
\end{tabular}


and $0.76 \mu \mathrm{g} / \mathrm{L}$ ) were similar to the median and mean glyphosate concentrations measured in various small and large stream and river systems throughout the continental United States $(0.32$ and $0.67 \mu \mathrm{g} / \mathrm{L})$, respectively. The frequency of glyphosate detection in Hawaiian and Continental United States stream and river systems was nearly identical (58 and 59\%).

\section{MATERIALS AND METHOD}

This study focused on collecting a series of stream samples during discrete rainfall runoff events from urban, agricultural and mixed-use watersheds on the island of Oahu, Hawaii. Unlike well studied stream and river systems in the continental United States, Hawaiian streams are generally flashy because tropical rainfall events are often intense, drainage basins are small, basins and streams are steep, and channel storage is limited. High frequency sampling was conducted during individual runoff events in this study to gain a better understanding of the variations in glyphosate concentration and glyphosate load that occur within Hawaiian streams throughout the runoff event. Runoff events associated with moderate to heavy rainfall intensity were sampled to assess pesticide concentrations in the stream resulting from storm runoff travelling across portions of the associated watershed as well as from potential resuspension of accumulated, glyphosate-contaminated sediments within the stream course of the monitored streams.

Fig. 1 shows the location of the five sampled streams on the island of Oahu and their associated watersheds.

One of the sampled streams (Honouliuli) is ephemeral and receives water from a watershed with relatively extensive amounts of agricultural activity including diversified agriculture and seed crops.

Honouliuli stream also receives water that is periodically released from the 42.6-kilometer long Waiahole irrigation ditch that transports dike-impounded groundwater captured from the windward side of Oahu to the drier leeward central plain. Two of the sampled streams (Waimanalo and Kahawai) are perennial streams that flow through mixed-use agricultural

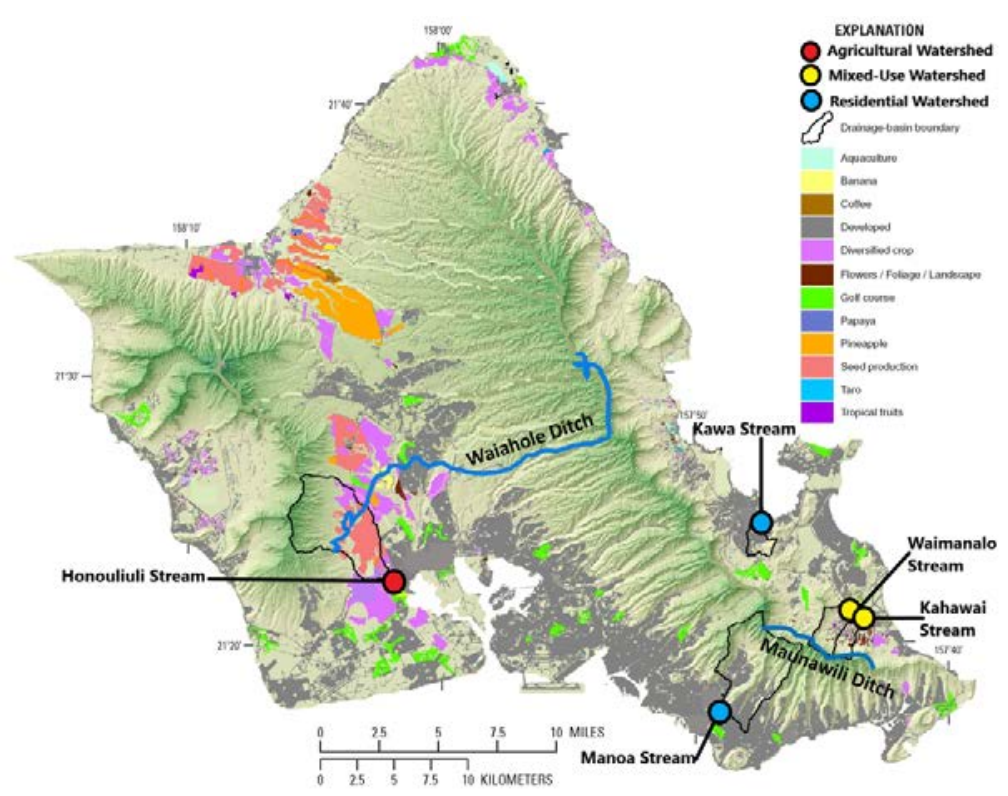

Figure 1: Map of Oahu showing stream sampling locations and land use. 
(plant nursery operations and small-scale livestock operations) and residential areas. These two streams also receive water periodically from the Maunawili Ditch system that consists of four miles of open ditches, pipe siphons, and tunnels as well as 10.5-miles of distribution pipeline that conveys surface and high-level groundwater from the adjacent wetter Maunawili watershed. Two of the sampled streams (Manoa and Kawa) are perennial streams that flow through residential communities on leeward and windward Oahu, respectively. Between storm events, baseflow to these four perennial streams is fed by perched or basal groundwater input.

\section{ELISA MONITORING}

Glyphosate concentrations in the stream samples were measured using the Abraxis Glyphosate ELISA Plate Kit. ELISA is an immunoassay-based method for the quantitative and sensitive screening of glyphosate levels in water samples. The concentrations of the samples are determined by interpolation using a standard curve constructed with each run.

The Glyphosate ELISA method has an estimated detection limit of $0.05 \mathrm{ppb}(\mu \mathrm{g} / \mathrm{L})$.

Correlation sampling was performed by the co-author during a prior study (Surfrider 2017). Surface water samples were split: one set of samples was sent to Vista Analytical for comprehensive analysis of glyphosate by HPLC-MS and the other was analyzed using the Abraxis ELISA field kit analytical method. The correlation coefficient determined for the six pairs of samples with results was $\mathrm{R}^{2}=0.95(95 \%)$, showing a strong correlation between the data produced by the laboratory analytical method and the ELISA method.

A total of ten field duplicate samples were run on two batches of samples analyzed for glyphosate using the ELISA method during this study. Table 2 shows the good replicability achieved on these field duplicate samples $\left(\mathrm{r}^{2}=0.987\right.$ for duplicate pairs with results). The samples analyzed during this study were not filtered in the field or in the laboratory prior to analysis but were decanted prior to performing the ELISA analysis. A subset of seven samples of moderate to high turbidity were chosen to evaluate whether the presence of suspended sediment in the samples effects the glyphosate concentration detected in the primary sample using the ELISA method.

Table 2: Field duplicate and shook sample results.

\begin{tabular}{|c|c|c|c|c|c|}
\hline \multicolumn{3}{|c|}{$\begin{array}{c}\text { Field duplicate glyphosate } \\
\text { concentrations }(\mu \mathrm{g} / \mathrm{L})\end{array}$} & \multicolumn{3}{c|}{ Shook sample glyphosate concentrations $(\mu \mathrm{g} / \mathrm{L})$} \\
\hline $\begin{array}{c}\text { Primary } \\
\text { sample } \\
\text { result }\end{array}$ & $\begin{array}{c}\text { Duplicate } \\
\text { sample } \\
\text { result }\end{array}$ & $\begin{array}{c}\text { Relative } \\
\text { percent } \\
\text { difference }\end{array}$ & $\begin{array}{c}\text { Primary } \\
\text { sample } \\
\text { result }\end{array}$ & $\begin{array}{c}\text { Re-suspended } \\
\text { sample result }\end{array}$ & $\begin{array}{c}\text { Primary sample } \\
\text { turbidity (NTU) }\end{array}$ \\
\hline 1.60 & 1.94 & $19.2 \%$ & 0.65 & 0.54 & 76 \\
\hline$>4.0$ & $>4.0$ & $0 \%$ & 1.84 & 1.59 & 389 \\
\hline 0.94 & 0.86 & $8.9 \%$ & $<0.05$ & $<0.05$ & 25 \\
\hline 0.75 & 0.97 & $25.6 \%$ & 0.16 & 0.14 & 388 \\
\hline 0.90 & 1.02 & $12.5 \%$ & 0.09 & 0.06 & 2,000 \\
\hline$<0.05$ & $<0.05$ & $0 \%$ & $<0.05$ & $<0.05$ & 160 \\
\hline$<0.05$ & $<0.05$ & $0 \%$ & 1.20 & 1.80 & 121 \\
\hline 0.12 & 0.16 & $28.6 \%$ & & & \\
\hline$<0.05$ & $<0.05$ & $0 \%$ & & & \\
\hline$<0.05$ & $<0.05$ & $0 \%$ & & & \\
\hline
\end{tabular}


The replicate samples were vigorously shaken after the decanted primary sample had been pipetted and a duplicate analysis was conducted on the resulting turbid sample. Table 3 shows that four of five of these shook, re-suspended samples yielded slightly lower glyphosate concentrations than the primary sample. This result suggests that the ELISA method does not detect glyphosate that may be sorbed to the entrained sediment present in the analyzed samples.

\section{FINDINGS}

Multiple stream samples were collected from fives streams during discrete rainfall events from February to April 2018. A single set of stream runoff samples were collected from Manoa, Waimanalo, Kahawai and Honouliuli streams while three discrete runoff events of varying size were sampled at Kawa Stream. The storm event hydrographs (in cubic meters per second $(\mathrm{cms}))$ and associated glyphosate concentrations $(\mu \mathrm{g} / \mathrm{L})$ measured in Manoa, Honouliuli, Kahawai, and Waimanalo streams are depicted in Fig. 2.

The Manoa Stream monitoring location receives rainfall runoff from the residential communities located in both Manoa and Palolo Valleys. Due to urbanization, the surface water flow to Manoa Stream is significantly altered from the "natural" state by the presence of impermeable surfaces, buildings, and on-going construction projects. The sampled storm for Manoa Stream on 3/31/2018 approached Oahu from the west just after noon. Due to the storm direction, the majority of the runoff that entered the stream during this rainfall event originated from rainfall runoff that fell on the residential communities located within Manoa and Palolo valleys. This likely contributed to the elevated glyphosate concentration levels detected in these samples. By comparison, the HDOH [15] and Surfrider [16] studies measured lower glyphosate concentrations in Manoa Stream ranging from $<0.075$ to 0.272 $\mu \mathrm{g} / \mathrm{L}$ ( $60 \%$ detection frequency).

Waimanalo Stream is a highly altered 5.5-kilometer long perennial stream that drains a $15.3 \mathrm{~km}^{2}$ watershed on the windward side of Oahu. The stream is composed of two main

Table 3: Glyphosate concentrations measured in storm and baseflow stream samples.

\begin{tabular}{|l|c|c|c|c|c|c|}
\hline \multirow{2}{*}{ Location } & Land use & $\begin{array}{c}\text { Median } \\
\text { detect } \\
(\mu \mathrm{g} / \mathrm{L})\end{array}$ & $\begin{array}{c}\text { Mean } \\
\text { detect } \\
(\mu \mathrm{g} / \mathrm{L})\end{array}$ & $\begin{array}{c}\text { Detect range } \\
(\mu \mathrm{g} / \mathrm{L})\end{array}$ & $\begin{array}{c}\text { Detect } \\
\text { frequency }\end{array}$ & $\begin{array}{c}\text { Sample } \\
\text { count }\end{array}$ \\
\hline Storm samples (rainfall runoff dominant streamflow) \\
\hline Manoa & Residential & 5.19 & 6.23 & $5.08-8.42$ & $100 \%$ & 3 \\
\hline Kahawai & Mixed use & 2.81 & 2.38 & $1.29-2.93$ & $100 \%$ & 5 \\
\hline Honouliuli & Agricultural & 1.04 & 1.16 & $0.47-2.16$ & $100 \%$ & 10 \\
\hline Kawa & Residential & 0.48 & 0.67 & $<0.05-1.84$ & $93 \%$ & 27 \\
\hline Waimanalo & Mixed use & 0.37 & 0.57 & $0.13-1.82$ & $100 \%$ & 8 \\
\hline Baseflow samples (groundwater dominant streamflow) & \\
\hline Manoa & Residential & 0.10 & 0.12 & $0.06-0.22$ & $100 \%$ & 4 \\
\hline Kahawai & Mixed use & 0.20 & 0.22 & $0.05-0.40$ & $100 \%$ & 3 \\
\hline Honouliuli & Agricultural & 0.10 & 0.13 & $0.05-0.30$ & $100 \%$ & 9 \\
\hline Kawa & Residential & $<0.05$ & 0.14 & $<0.05-0.91$ & $31 \%$ & 13 \\
\hline Waimanalo & Mixed use & $<0.05$ & 0.07 & $<0.05-0.21$ & $40 \%$ & 5 \\
\hline${ }^{1}$ Detection limit $=0.05 \mu \mathrm{g} / \mathrm{L}$ & \\
\hline
\end{tabular}



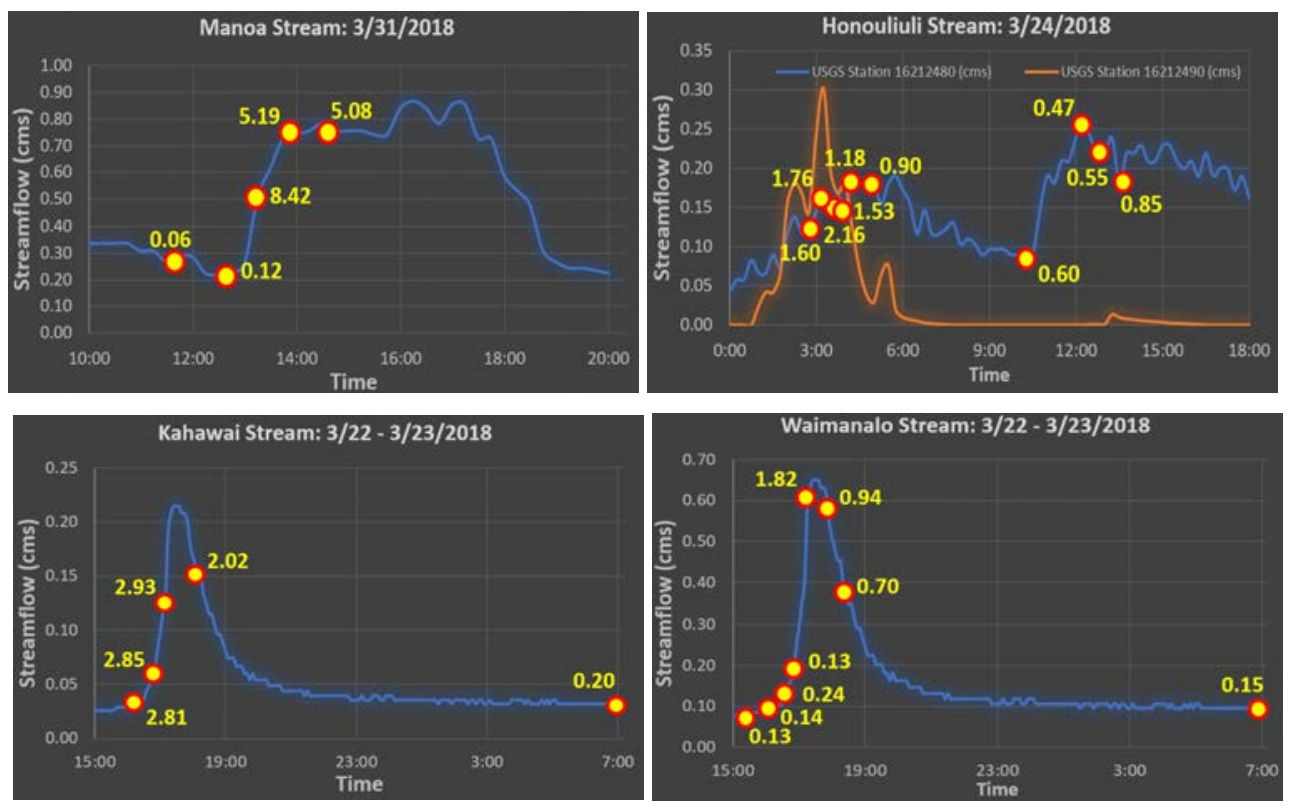

Figure 2: Stream storm event hydrographs and glyphosate concentrations ( $\mu \mathrm{g} / \mathrm{L})$.

segments shaped like the letter Y, with the southeastern tributary identified as Kahawai Stream and the northwestern tributary, named Waimanalo Stream. The Waimanalo watershed through which these streams flow has retained much of its rural character and contains both residential and agricultural land use, including numerous small plant nursery operations and small-scale livestock operations (mostly horses and chickens). The sections of both streams that run through residential areas have been channelized for flood control purposes. Waimanalo Stream is designated as a Water Quality Limited Segment for failing to meet the State's water quality standards, particularly total nitrogen and nitrate levels in the Kahawai segment of the stream.

Honouliuli stream is normally dry and only flows during heavy rainfall events or when water is released from the terminus of the Waiahole Ditch system. The water in the Waiahole ditch is recovered from high-level groundwater aquifers located on the windward side of the island. Honouliuli stream was receiving a combination of storm runoff and ditch release water on the day high frequency sampling was conducted (3/24/2018). Fig. 2 shows the hydrographs recorded at two USGS stations located roughly 4 kilometers apart on Honouliuli Stream: the mountain station (16212480) records ephemeral runoff from the Waianae mountain range that enters the stream while the lower station (16212490) is located below the Waiahole Ditch release point and the confluence of the Honouliuli tributary that runs through seed crop and diversified agricultural lands. Seepage runs made by the USGS in the section of stream between these two USGS gaging stations measured seepage loss rates from 0.27 to 1.78 million gallons per day per mile of stream reach [17]. This finding is significant since the lower gaging station is located near a large groundwater supply battery (the Ewa Shaft (State well 3-2202-21)) that extracts water from a lateral skimming shaft constructed along the top of the groundwater table, which may be impacted by infiltration of agricultural released pesticides present in Honouliuli Stream. 
Fig. 3 shows the hydrograph and stream glyphosate concentrations measured in Kawa Stream over a four-month period between mid-December 2017 and early April 2018. The figure differentiates stream samples and their associated glyphosate concentrations collected under groundwater dominant baseflow conditions (blue circles) from samples collected under high-streamflow, storm conditions (red dots).

Kawa Stream is a perennial stream composed of approximately 4.5 kilometers of main and tributary stream courses located within a 2.93-square kilometer watershed in Kaneohe, Hawaii. Kawa stream is perennial due to baseflow that originates from springs located throughout the watershed which are fed by shallow, likely discontinuous perched groundwater bodies. The watershed contains both upland forestland and comparatively impervious residential areas which (along with roadways) are estimated to cover approximately $40 \%$ of the total watershed. The urbanized areas within the watershed include two cemeteries, elementary and high schools, parks, as well as residential and commercial developments.

\section{DISCUSSION}

Table 3 summarizes the glyphosate concentrations measured in the five streams sampled under storm (53 samples) and baseflow ( 34 samples) conditions during this investigation. Glyphosate was detected in $96 \%$ of the stream samples collected under storm conditions (detection limit $=0.05 \mu \mathrm{g} / \mathrm{L}$ ). Glyphosate was detected in $65 \%$ of the stream samples collected under baseflow conditions. The mean and median glyphosate concentrations measured in the same streams were much higher during elevated stream flow conditions than under dry, baseflow conditions when groundwater input to the streams dominated. In addition, the glyphosate concentrations measured in streams that received runoff from an urban area (Manoa Stream) were somewhat higher than glyphosate concentrations measured in streams receiving runoff predominately from agricultural areas (Honouliuli Stream).

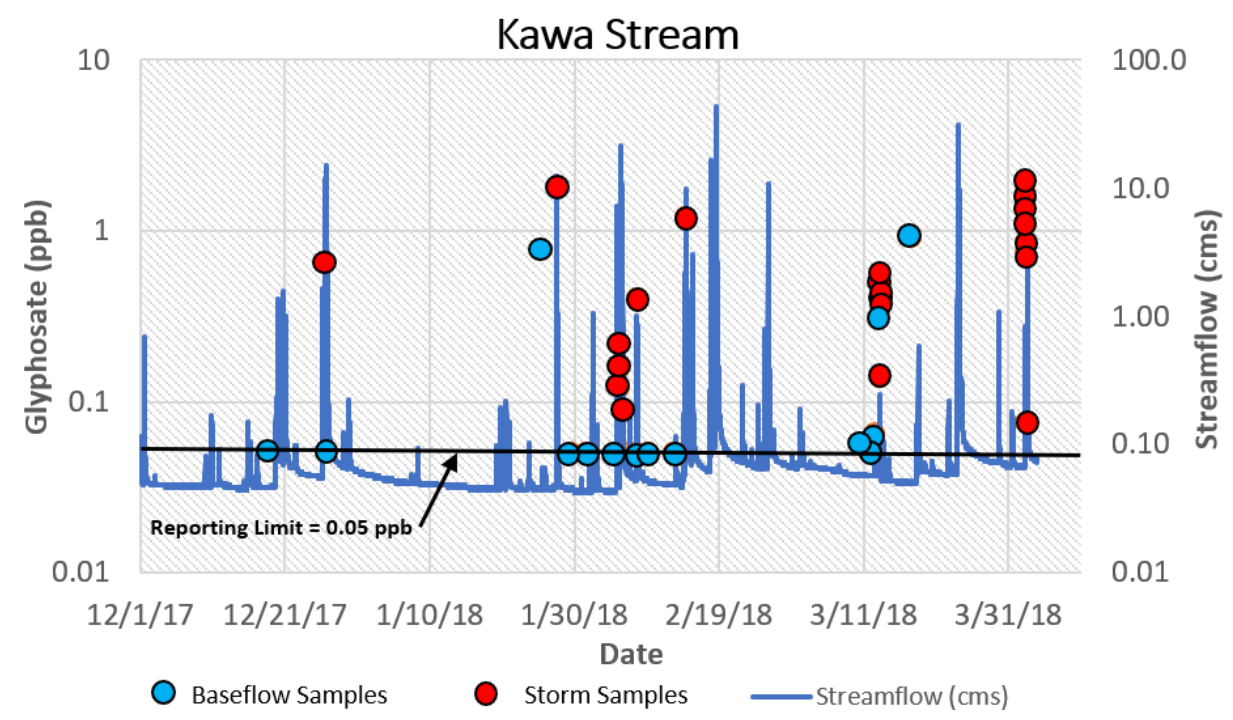

Figure 3: Kawa stream hydrograph and glyphosate concentrations $(\mu \mathrm{g} / \mathrm{L})$. 
The findings from this study indicate that glyphosate is more prevalent and present at higher concentration levels than any of the 225 other pesticide compounds being analyzed during an ongoing USGS pesticide monitoring program of Hawaiian surface waters [4]. Hydroxyatrazine, a degradation product of atrazine, was the most commonly detected pesticide during the ongoing USGS monitoring program and during the previous $\mathrm{HDOH}$ study [15].

It is likely that AMPA, the degradation product of glyphosate, is also present in Hawaiian streams at higher frequencies than detected during this study, consistent with findings from other large-scale glyphosate sampling studies in streams [12].

Previous studies have attributed the high frequency of detection of glyphosate in streams to its high solubility and persistent applications in agricultural and urban settings for weed control along roadsides and ditches as well as ubiquitous household use [12].

The addition of surfactants and other adjuvants to glyphosate formulations may also have increased glyphosate's mobility in the environment.

Rain intensity has also been found to be an important factor for the offsite transport of glyphosate [18]. Soil particle movement in runoff generated by heavy rainfall will carry adsorbed glyphosate, which will end up in surface water where it can be desorbed, degraded or stored in sediments [19].

Weekly monitoring of glyphosate and AMPA concentrations within four agricultural basins in Iowa, Indiana, Mississippi and France found that the glyphosate load measured in the stream ranged from 0.009 to $0.86 \%$ of the glyphosate mass applied within each associated watershed [20]. The observed differences in the percentage of applied glyphosate that ended up in the stream included: 1) when and how the glyphosate was applied within the basin (source strength), 2) the amount, frequency and duration of rainfall events or irrigation within the basin (rainfall runoff), and 3) whether the majority of rainfall reaches the stream by overland flow or by subsurface drainage (flow route). Because glyphosate degrades, its frequency of occurrence is dependent upon the timeframe of its local application. In Mississippi, where the application of pesticides is almost continuous, glyphosate and AMPA were detected in almost every sample, whereas in Iowa, where the use of glyphosate is more temporally restricted, glyphosate and AMPA were not as frequently detected.

Unfortunately, the mass of glyphosate applied to the watersheds contributing runoff to the streams sampled during in study is not known. Based on the general land use of areas contributing runoff to the sampled streams, it is estimated that the highest usage of glyphosate per acreage of watershed is: Honouliuli $>$ Kahawai $>$ Waimanalo $>$ Kawa $>$ Manoa. Despite this estimate, Manoa Stream contained the highest concentration levels of glyphosate. The high concentrations measured in Manoa Stream are likely an artifact of the nature of the particular storm event sampled. The majority of the runoff generated during this "Kona" storm event came from the residential portions of Manoa and Palolo Valleys and were not "diluted" by runoff from the surrounding forested mountain watersheds which likely contain little or no glyphosate. The paved surfaces in the residential communities within these two valleys also likely more efficiently transport glyphosate containing top soils from residential yards and street medians to the stream during moderate intensity rainfall events such as the one sampled. Fig. 4 plots the glyphosate concentrations versus the turbidity measured in the stream samples analyzed during this study.

Fig. 4 shows the generally lower glyphosate concentrations measured in low turbidity samples $(<40 \mathrm{NTU})$ typically associated with baseflow conditions and the generally higher glyphosate concentrations measured in more turbid samples ( $>40$ NTU) typically associated with storm conditions. This finding supports the hypothesis that the source of some of the glyphosate measured in the stream samples during the storm events sampled originated from 


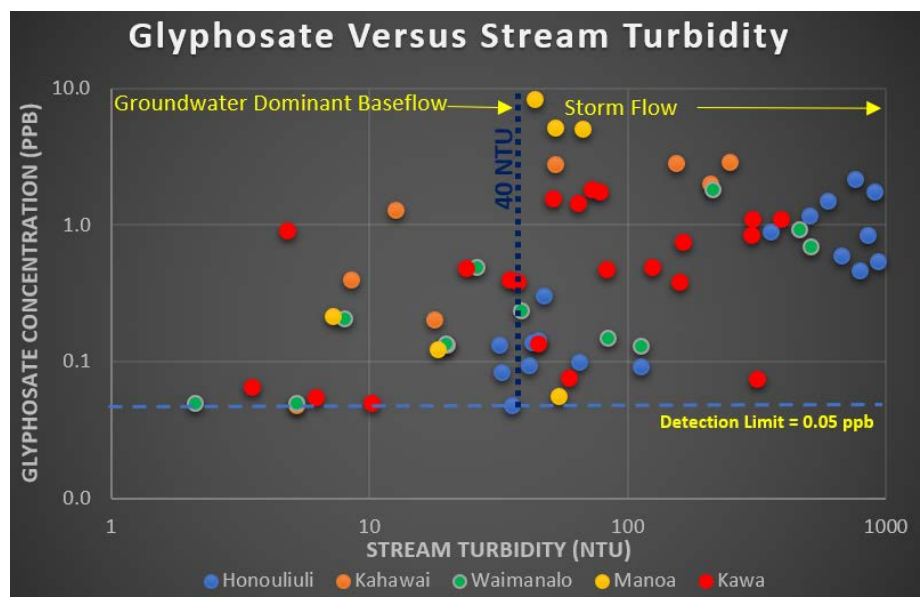

Figure 4: Relationship between glyphosate concentration and stream turbidity.

release of sorbed glyphosate present in contaminated sediments as they become resuspended from the stream bed during moderately intense storm runoff events.

The mass of glyphosate present in stream water during the monitored runoff events was estimated as the product of the glyphosate concentrations measured in the stream (micrograms per liter) and the stream flow rates measured at the associated USGS gaging station. The gaging stations typically recorded stream flow at either a five or fifteen-minute time intervals. The glyphosate concentration in the stream was estimated for the same five or fifteen-minute time intervals based upon extrapolation of the individual glyphosate concentrations measured in the stream throughout the duration of each monitored storm event (Figs 2 and 3). Table 4 summarizes the duration of the monitored storm events, the storm event rainfall totals, the total volume of streamflow during the monitored event, and the calculated mass of glyphosate present in stream water during the monitored event.

The concentration of glyphosate and AMPA in suspended samples collected from Waimanalo, Honouliuli and Kawa Streams were determined by Pacific Agricultural Laboratory in Sherwood, Oregon. These composite suspended sediment samples were collected by repeatedly filling up three five-gallon buckets with stream water collected over a thirty-minute time period during the rainfall runoff event. The Waimanalo Stream suspended sediment sample was collected between $17: 15$ and $17: 45$ on $3 / 22 / 18$; the

Table 4: Runoff event duration, rainfall, runoff volume and glyphosate mass.

\begin{tabular}{|l|c|c|c|c|}
\hline Stream & $\begin{array}{c}\text { Sampled runoff event } \\
\text { duration }\end{array}$ & $\begin{array}{c}\text { Rainfall } \\
\text { event total } \\
\text { (mm) }\end{array}$ & $\begin{array}{c}\text { Stream volume } \\
\text { during sampling } \\
\text { (L) }\end{array}$ & $\begin{array}{c}\text { Glyphosate } \\
\text { mass during } \\
\text { event (gm) }\end{array}$ \\
\hline Manoa & $3 / 31 / 18: 11: 45$ to $14: 30$ & 6.4 & $5,333,094$ & 14.4 \\
\hline Waimanalo & $3 / 22 / 18: 15: 45$ to $18: 30$ & 5.1 & $3,427,271$ & 11.9 \\
\hline Kahawai & $3 / 22 / 18: 15: 45$ to $18: 30$ & 5.1 & $1,131,000$ & 3.4 \\
\hline Honouliuli & $3 / 24 / 18: 2: 55$ to $13: 30$ & 51.3 & $6,063,241$ & 5.4 \\
\hline Kawa & $2 / 5 / 18: 6: 40$ to $17: 00$ & 29.2 & $125,987,860$ & 18.0 \\
\hline Kawa & $3 / 13 / 18: 5: 00$ to $8: 30$ & 6.4 & $1,152,020$ & 0.5 \\
\hline Kawa & $4 / 2 / 18: 7: 00$ to $10: 15$ & 12.7 & $4,330,925$ & 4.8 \\
\hline
\end{tabular}


Honouliuli Stream suspended sediment sample was collected between 12:15 and 12:45 on 3/22/18; and the Kawa Stream suspended sediment sample was collected between 9:00 and $9: 30$ on $4 / 2 / 18$. The total mass of glyphosate present in the suspended sediment during this thirty-minute period of time was estimated based upon the turbidity levels measured in the stream samples collected during this portion of the storm event. The turbidity levels were converted to a total suspended solids concentration using relationships between turbidity and TSS developed during this study, historic USGS water quality measurements, and from measurements made during previous environmental studies [21]. The glyphosate and AMPA concentrations measured in the suspended sediment samples collected in Honouliuli, Waimanalo and Kawa streams were $0.25 / 0.39,0.75 / 0.63$ and $0.82 / 1.0 \mathrm{mg} / \mathrm{kg}$, respectively. The corresponding mass of glyphosate in suspended sediments present in these three streams during the thirty-minute time interval sampled were $0.05,0.17$ and 0.15 grams, respectively. By comparison, the mass of glyphosate dissolved in the stream water during this same thirtyminute time interval of the runoff event was $0.22,1.55$ and 0.82 grams, respectively. Based on this limited suspended sediment data, the glyphosate in suspended sediment represents between $11 \%-23 \%$ of the total glyphosate load in the stream.

Because of the duration of monitoring (four months) and number of sampled storm events (3) at Kawa Stream, the mean and median glyphosate concentrations measured under baseflow and storm conditions from Kawa Stream are the most representative data for evaluating the magnitude of glyphosate transport to the offshore environment via streams in Hawaii. The total mass of dissolved phase glyphosate transported over this four-month period in Kawa Stream was estimated by multiplying the stream flow measured under baseflow conditions (stream flow $<0.10 \mathrm{cms}$ ) during this period by the mean baseflow glyphosate concentration measured over this four-month period $(0.14 \mu \mathrm{g} / \mathrm{L})$ and the storm related stream flow $(>0.10 \mathrm{cms})$ by the storm event mean glyphosate concentration $(0.67 \mu \mathrm{g} / \mathrm{L})$. The resultant total dissolved phase glyphosate mass input into Kaneohe Bay (the adjacent coastal body) is 987 grams for this four-month period, with about $92 \%$ of the load entering the bay during storm runoff events.

\section{CONCLUSIONS}

High-frequency sampling for glyphosate in five streams on the island of Oahu revealed the ubiquitous nature of this herbicide in both agricultural and urban settings as reflected by the high rates of detection measured during both storm and baseflow conditions $(96 \%$ and $65 \%$, respectively). Measured stream glyphosate concentrations were generally significantly higher under storm conditions than under groundwater dominant baseflow conditions. The source of some (or perhaps a majority) of the glyphosate measured in the stream samples is likely from release of sorbed glyphosate present in sediments as they become re-suspended from the stream bed during storm runoff events. During the limited sampling conducted in this study, glyphosate concentrations measured in streams receiving runoff from an urbanized watershed (Manoa) was higher than concentrations measured in streams that flow through agricultural areas on Oahu. The mass of glyphosate measured discharging to the coastal environment during the monitored storm events ranged from 0.5 to 18 grams while the total mass of glyphosate discharging from one of the monitored streams (Kawa) over a four-month period was estimated to be around 1 kilogram.

\section{REFERENCES}

[1] Green, R.E., Goswami, K.P., Mukhtar, M. \& Young, H.Y., Herbicides from cropped watersheds in stream and estuarine sediments in Hawaii. Journal of Environmental Quality, 6(2), pp. 145-154, 1977. 
[2] Oki, D.S. \& Brasher, A.M.D., environmental setting and the effects of natural and human-related factors on water quality and aquatic biota, Oahu, Hawaii. United States Geological Survey, Water-Resources Investigations Report 03-4156, 2003.

[3] Brasher, A.M. \& Anthony, S.S., Occurrence of organochlorine pesticides in stream bed sediment and fish from selected streams on the island of Oahu, Hawaii, 1998: U.S. Geological Survey Fact Sheet 140-00, p. 6, 2000.

[4] Steinrücken, H.C. \& Amrhein, N., The herbicide glyphosate is a potent inhibitor of 5enolpyruvyl-shikimic acid-3-phosphate synthase. Biochemical and Biophysical Research Communications, 94(4), pp. 1207-1212, 1980.

[5] Benbrook, C., Trends in the use of glyphosate herbicide in the U.S. and globally. Environmental Sciences Europe, 28(3), 2015.

[6] Grube, A.D.D., Kiely, T., \& Wu, L., Pesticides Industry Sales and Usage, 2006 and 2007 Market Estimates, United States Environmental Protection Agency, EPA 733-R11-001, 34 p. 2011. http://1.usa.gov/1VN2QDo, 2011.

[7] Wittmer, I.K., Scheidegger, R., Bader, H., Singer, H. \& Stamm, C., Loss rates of urban biocides can exceed those of agricultural pesticides. Science of the Total Environment 409, pp. 920-932, 2011.

[8] Connor, M.S. et al., The slow recovery of San Francisco Bay from the legacy of organochlorine pesticides. Environ. Res., 105, pp. 87-100. 2007.

[9] Szekacs, A. \& Darvas, B., Forty years with glyphosate. Herbicides - Properties, Synthesis and Control of Weeds, ed. N. Hasaneen, M. InTech, 2012. doi: $10.5772 / 32491$.

[10] Bento, C.P.M. et al., Persistence of glyphosate and aminomethylphosphonic acid in loess soil under different combinations of temperature, soil moisture and light/darkness. Sci. Total Environ., 572, pp. 301-311, 2016.

[11] Battaglin, W.A., Meyer, M.T., Kuivila, K.M. \& Dietze, J.E., Glyphosate and Its Degradation Product AMPA Occur Frequently and Widely in U.S. Soils, Surface Water, groundwater, and precipitation. Journal of the American Water Resources Association (JAWRA), 50(2), pp. 275-290, 2014. doi: 10.1111/jawr.12159.

[12] Horth H., European Glyphosate Environmental Information Source (EGEIS), Monitoring results for surface and groundwater. www.egeis.org/documents/11\%20 Detection\%20in\%20SW\%20and\%20GW\%20draft\%20v3.pdf, 2010.

[13] Chang, F, Simcik, M.F. \& Capel, P.D., Occurrence and fate of the herbicide glyphosate and its degradant aminomethylphosphonic acid in the atmosphere. Environ. Toxicol. Chem., 30, pp. 548-555, 2011.

[14] Hawaii Department of Health (HDOH) Hazard Evaluation and Emergency Response Office. 2013-2014 State Wide Pesticide Sampling Pilot Project Water Quality Findings. A joint investigation by the Hawaii State Departments of Health and Agriculture, May 2014.

[15] Surfrider Foundation, Water Quality Study of Nearshore Environments, Oahu, Kauai and Molokai, Hawaii. Final Project Report, Version 1.1, Aug. 2017.

[16] Rosa, S.N., Measuring surface-water loss in Honouliuli Stream near the 'Ewa Shaft, Oahu, Hawai‘i: U.S. Geological Survey Scientific Investigations Report 2017-5042, p. 14, 2017. https://doi.org/10.3133/sir20175042.

[17] Johnson, A.G. \& Kennedy, J.J., Summary of dissolved pesticide concentrations in discrete surface-water samples collected on the islands of Kauai and Oahu, Hawaii, Nov. 2016-Apr. 2017, U.S. Geological Survey data release, 2018. https://doi.org/ 10.5066/F7BG2N79. 
[18] Yang, X.M. et al., Short-term transport of glyphosate with erosion in Chinese loess soil - a flume experiment. Sci. Total Environ., 512, pp. 406-414, 2015.

[19] Todorovic-Rampazzo, G., Rampazzo, N., Mentler, A., Blum, W.E.H., Eder, A. \& Strauss, P., Influence of soil tillage and erosion on the dispersion of glyphosate and aminomethylphosphonic acid in agricultural soils. Int. Agrophysics, 28, pp. 93-100. 2014.

[20] Coupe, R.H., Kalkhoff, S.J., Capel, P.D. \& Gregoire, C., Fate and transport of glyphosate and aminomethylphosphonic acid in surface waters of agricultural basins. Pest Management Science, 68, pp. 16-30. 2011.

[21] Tomlinson, M. \& DeCarlo, E., Final Report - Investigations of Waimanalo and Kaneohe Streams, p. 30, 2001. 